\title{
COOPERATIVE ASSESSMENT WRITING PRACTICES AT AN ACEHNESE PRIVATE UNIVERSITY: HELPING OR TROUBLING?
}

\author{
Saiful Akmal \\ Universitas Islam Negeri Ar-Raniry \\ saiful.akmal@ar-raniry.ac.id \\ Syarifah Dahliana \\ Universitas Islam Negeri Ar-Raniry \\ syarifah.dahliana@ar-raniry.ac.id \\ Rani Fadhila \\ Universitas Islam Negeri Ar-Raniry \\ rani.fadhila96@gmail.com
}

\begin{abstract}
A good writing skill could be a benchmark of someone's good ability in English. This study aims to find out how the practice of cooperative assessment can diminish errors and mistakes in students' writing and to see students' view towards cooperative assessment method in writing class. Qualitative approach by using case study method was used in this study, and the data were taken by means of observation, document analysis and interview towards the fourth semester students of a university in Banda Aceh, Serambi Mekah University Banda Aceh, Indonesia in 2018/2019 academic year. The findings showed that there were three techniques of cooperative assessment that may lessen errors and mistakes in students' writing, namely; peer review, lecturers' feedback and classroom reviewing activity. In students' view, cooperative assessment has some benefits (improving grammatical awareness, improving students' vocabularies, and improving the structure of students' writing) as well as drawbacks (peer errors in editing and time consuming). Therefore, it is recommended that students make their errors and mistakes diary notes and lecturers are advised to start making grammar errors and mistakes checklists based on the learning objectives for students' peer reviewing practice.
\end{abstract}

\section{Keywords}

Cooperative Assessment, Private University, Writing Practices 


\section{INTRODUCTION}

Writing is one of the most major English skills that should to be mastered. According to Cole (2015, p.5), "writing has always been seen as an important skill in English language acquisition. This importance is due to the fact that it supports the grammatical structure and vocabulary that encourages educators to educate their students". As a result, many people are encouraged to improve their writing skill. Some people focus in developing ideas while some others emphasis on the structure of writing to make a better writing. However, good ideas and perfect structure do not always promise the success of writing. Some minor mistakes and grammatical errors one way or another could hamper the final product of writing. Amin (2014) said that a good written communication is predisposed by a good grammar understanding, because incorrect grammar selection will result serious misinterpretations for the readers. This is why reducing errors and mistakes in writing is vital. Another reason is because people very often failed to spot their own mistake, but, they can clearly notice others.

As assessment has become inseparable in teaching and learning practice, the need to comprehend its definition is also equally important. According to Brown (2004, p.275), "assessment is an activity which covers the whole action that students make in the classroom", unconsciously or consciously measured by the lecturers. Generally speaking, thus, there are several types of assessment which is implemented in education. For example, examination, essays, portfolios, project, reviews and annotated bibliographies, self, peer and group assessment. The last one is universally known as cooperative assessment.

Cooperative assessment involves more than two person to assess student's performance. Cooperative or group assessment found under 
cooperative learning approach which put strong emphasis to cooperation in group. It is also known as one type of collaborative learning, mutual learning and the likes where students are individually responsible for their own effort, but the whole work of the group is also considered (Balagiu, Patesan and Zechia, 2016). With cooperative learning, students can learn how to manage themselves within the group, to rely on each other and to make a successful writing product.

In the same light, Quarstein and Peterson (2001) argue that cooperative assessment is a goal-oriented approach which can foster incremental development and adaptions for students. Simply put, Slavin, Hurley and Chamberlain (2007) summarizes the four perspectives on cooperative learning and assessments, which are motivational, social cohesion, cognitive development, and cognitive elaboration.

\section{LITERATURE REVIEW}

In the eye of Graham and Hebert (2016) writing is a form of communication that is complex, diverse and directed which is completed in a variety of environments, under different times, and with various language resources and technological tools. Writing can be simply interpreted as a process of exploring thoughts and feelings towards a subject. It then encourages the writer to deliberately deliver the information in a good language order. It is categorized into the productive skills in English language learning, unlike listening and reading all known as receptive skill in English language learning.

In teaching writing, here are thus two shared approaches; the product approach and the process approach. Klimova (2013, p.148) explained that, "the product approach to writing usually involves the presentation of a 
model text, which is discussed and analyzed, while the process approach to writing in contrast focuses on the development of language use; brainstorming, group discussion, re-writing”. Product and process approaches can both be implemented in context-dependent situation of teaching.

Consecutively, writing always bring errors and mistakes along. Mistakes are usually wrong choices in writing. Learners know the system but fail to practise it. Mistakes are performance error and can be self-corrected. On the other hand, an error cannot be self-corrected while mistake can be self-corrected if the deviation is pointed out to the speaker. Feltsen (2009, p.6) also said, "errors are something that we cannot correct; it is something that we will have to learn in order to correct and understand, while mistakes can be corrected as the knowledge is already learnt". Students might make an error when they think that what they assume (without any knowledge) is correct while it is actually incorrect.

To be able to evaluate the teaching of writing, the assessment part is inevitable. Assessment is required to measure students' understanding about a lesson by collecting information by using test or non-test procedures. Assessment is then likewise imperative for students' forthcoming enhancement. Saad and Sardareh (2013) supposed that assessment call for teachers to review learners' progress, to provide them with advice and to agree upon the follow up treatment of the teaching and learning process.

\section{METHOD}

This study used qualitative case study approaches because qualitative data collection is generally depend on interpretation. The methodology that was used in this research is a case study method. Zainal (2007) said that in case study method a researcher is facilitated to closely explore the data in a 
specific context. In addition, the target population of this research were the fourth grade semester students of a University in Banda Aceh. They were fourth semester students purposively selected for they were going to join in academic writing class in the next semester. Purposive sampling let the researcher to find proper participants who can provide information based on their knowledge or experience to answer the research questions which are needed by the researcher (Tongco, 2007).

In collecting the data, the writer used three instruments, they are observation, document analysis and interview. The observation is aimed to see the way of cooperative assessment reduce errors and mistakes in students' writing from the first to the third meeting this method has been applied. Interview was used to collect the data for the need to explore student view in cooperative assessment.

\section{FINDINGS AND DISCUSSION}

1. Practicing Cooperative Assessment in the classroom: the challenges

The writer joined three meetings of the class as the observant and as the corrector of students' writing to observe how cooperative assessment method could improve students writing during the teaching learning process. Students' writing tasks were collected and analyzed based on the fourteen types of errors introduced by Azar (1989, cited in Cholipah 2014, p.26).

All students were asked to write an argumentative paragraph on a piece of paper related to the issues they have chosen within fourth five minutes. After that, each student must exchange their writing with a friend to be reviewed before it gets collected back by the writer. Having reviewed by friend, the errors and mistakes on students' writing must be corrected and copied on a new paper. As a result, the total writing that must be collected by 
the students was two writings, the writing that had been reviewed by friends, and the text that had been corrected.

Having analyzed students' writing from three meetings, the result showed some student writing performance's improvement since cooperative assessment was applied in the writing class. The following table presents the results of students' errors analysis

Table 1

Students' improvements from the first, second, to the third meeting.

\begin{tabular}{|c|c|c|c|c|}
\hline No. & Types of errors & $\begin{array}{c}\text { First } \\
\text { writing }\end{array}$ & $\begin{array}{l}\text { Second } \\
\text { writing }\end{array}$ & $\begin{array}{l}\text { Third } \\
\text { writing }\end{array}$ \\
\hline 1. & Singular-plural & 1 & 2 & 4 \\
\hline 2. & Word form & 0 & 1 & 1 \\
\hline 3. & Word choice & 6 & 3 & 8 \\
\hline 4. & Verb tense & 5 & 4 & 3 \\
\hline 5. & Add a word & 7 & 4 & 1 \\
\hline 6. & Omit a word & 5 & 2 & 4 \\
\hline 7. & Word order & 1 & 2 & 0 \\
\hline 8. & Incomplete sentence & 9 & 3 & 5 \\
\hline 9. & Spelling & 3 & 0 & 1 \\
\hline 10. & Punctuation & 16 & 4 & 7 \\
\hline 11. & Capitalization & 3 & 7 & 1 \\
\hline 12. & Article & 2 & 0 & 4 \\
\hline 13. & Meaning not clear & 8 & 5 & 1 \\
\hline 14. & Run-on sentence & 8 & 9 & 3 \\
\hline & Total & 74 & 46 & 43 \\
\hline & Percentages & $45,40 \%$ & $28,22 \%$ & $26,38 \%$ \\
\hline
\end{tabular}


From the table above, we can see that there was a slight improvement since cooperative assessment was introduced in the writing class. There were 73 total errors of students' writing in the first meeting (45,40\%). Meanwhile, the number of students' errors in the second meeting decreased to 46 errors $(28,22 \%)$, and total errors made by students in the last meeting was 43 errors $(26,38 \%)$. It proves that, despite short time span of cooperative assessment implementation, this approach is very helpful for students to reduce their errors and mistakes in writing, especially in writing argumentative paragraph.

This was the result of the combination between peer review and lecturer's feedback towards each errors and mistakes that student has made in their writing. This result is in line with the benefits of Cooperative Learning Structures method which was developed by Kagan in 1985. This form of learning provides opportunities for students to discuss with peers, group learning, and teachers. Laguador (2014) also added that these cooperative learning strategies enable students to work as teams, partner, and classmate. When a student get her/his writing to be corrected by her/his friends, she/he (whose the writing has been corrected) can be easier to accept the information given by another friend because there is no reluctance or shame in communicating with her/his friend so that the students can learn from each other.

\section{Students' view: the benefit and drawback of practicing cooperative assessment}

There are several benefits and drawback that the student perceives from practising cooperative assessment in writing class. The benefits may improve grammatical awareness, vocabulary mastery and the macro and micro structure of writing. On the other hand students feel that peer error while 
reviewing, and time consumption were the most frequent drawbacks in implementing cooperative assessments.

\subsection{The Benefit}

Improve grammatical awareness

Based on the interview results, students believe that cooperative assessment can helps students improving their grammatical awareness. Not only that it also specifically helps them to write in a better word order, punctuation, also correct use of capitalization. This statement is found from the following interview excerpts:

Interviewee 2 suggests:

Cooperative assessment makes me able to know about the paragraph writing, how to write in a good order, use proper punctuation \&capitalization the lecturer give in our class. (Day 1. May 16, 2019)

The other students also agree if cooperative assessment helps her in improving her writing skill. For example, interviewee 3 summons:

yes, it solves my grammar problem, because in my writing, I know I have made sometimes wrong grammar choice that when I exchange paper with my friend and my friend assessed my writing and she corrected me and I read the correction, and I can improve by that, so I can learn again what mistake I have made. (Day 1. May 16, 2019)

Those excerpts indicate that almost all students believed if cooperative assessment could improve their grammatical awareness especially in the correct use of word order, capitalization and punctuation. They have faith in cooperative assessment that with the help of peer assessment they can learn more. They also can easily understand the errors and mistakes they 
made by practicing mutually review and correction works between them. As a result, they felt that they are more motivated to try not to make the same mistakes in the future again.

Improve vocabulary mastery

Apart from reducing errors in writing, students believe that this method makes them having an increased mastery of the vocabulary. This can be obtained from the students' statement as follows.

Interviewee 5 argues:

$y$, the beneficial right, the advantages of cooperative assessment is it can increase me and your vocabulary and then also we can know about how to use punctuation correctly, and then will make my knowledge improved, ya will improve my knowledge. (Day 1. May 16, 2019)

From the above comments, it is safe to say that students increased mastery of vocabulary can be gained by paying attention to other friends' writing. When they are correcting a text, they also learned the vocabularies written in their friend's writing. This can help them raising their level of language awareness of some new vocabularies they had never heard before.

Improve the structure of writing

Cooperative assessment also improves the structure of writing. As mentioned by Interviewee 1 below:

one, I maybe, one number one, I can know how to use English well, and then how to use grammar in the statement, that is number two, and number three maybe I can know structure, and then I know how to tell to my friend while their statement error or not error. Ya, from this I can learn something from my friends and I can share to my friend too. (Day 1. May 16, 2019) 
When peers assess student's writing, they not only assess one aspect but also the whole component of writing. Here, students also got improvement of their writing structure by sharing their knowledge in cooperative environment. These positive activities bring the positive outcome for student's creative and critical thinking. The more students learn their mistakes the better their writing will be.

\subsection{Drawbacks}

Peer errors in editing

The first drawback is peers' errors in editing their friends' paper. Considering the fact that students who are still in the learning process have higher possibility to make mistakes when checking the writing of another friends' writing. This is supported by students statements in the following section. For instance, interviewee 6 addresses:

yaa. yaa.. some of them make mistake in correct my paper, then when I get my paper back I just see which one is my mistake in that paper, and then when I see that's wrong then I will ask to my my lecturer and then my lecturer will say to me which one is which one is... the correct one, and then when my lecturer already told me about the mistake then I will tell to my friends that the correct one is this and my friend also get something from that. (Day 2. May 17, 2019).

Time consuming

The second drawback is time consuming dilemma. Writing is known as one of the most demanding skill in English. Someone needs time to think a good idea and to think about what it is worth to write. Since the writing class duration is short, this cooperative method made it even more or rather difficult to implement in the class. It is like identified by a participant below. Interviewee 8 supposes: 
Time is not enough, because when we are asked to write something, we think. first, and then it's already 15 minutes left and it's going to be exchanged to friends. After the exchange is checked, then we write again the correct one. So it takes time. (Day 2. May 17, 2019)

However, when the interviewer asked them about whether they agree to use this cooperative method in the writing class most of them were very enthusiastically agreed to use cooperative assessment method. As an example, Interviewee 6 highlights:

sure, because that's really great, that's have a lot of advantages in cooperative assessment, we can, like what I said again to you before, that's really nice for our grammar and we know which where we need to make punctuation, capitalization, because every meeting we get feedback from friends and lecturer. So I suggest that. (In6. Day 2. May 17, 2019)

It shows that cooperative assessment must have given a very good encouragement on them which lead them to suggest using cooperative assessment for others in the writing class. All students therefore agreed to use cooperative assessment in writing class regardless its drawbacks. The data show that cooperative assessment helps students to expose and build their grammatical awareness especially in avoiding errors. It also improves their vocabulary by reading friends' writing because when they find a new vocabulary from friend's writing, they will look at the meaning of it, which is very positive development from the practice.

\section{CONCLUSION}

The data presented that cooperative assessment can reduce errors and mistakes especially in grammatical aspects. We read this as a success of errors reduction treatment in students' writing. On the most influential 
activity, students were enthusiastically taking part in peer review, teacher feedback and classroom reviewing activity in each meeting. Small discussions between students and peers and students and lecturer which have been done every day in the class can improve students' knowledge and increase students' critical thinking. This is also supported by the results of interviews with the students regarding the use of cooperative strategy after they were involved within the class progresses. Most of the students agreed that using cooperative assessment strategy in writing class was beneficial for their writing ability, such as improving their grammatical awareness, improving their vocabulary and also improving their writing structured as well.

\section{REFERENCES}

Amin, B. (2014). Lexical error in writing English words made by students of the junior high school. Jurnal Pendidikan Bahasa dan Sastra Inggris, 3(1), 107-133.

Brown, H. D. (2004). Language assessment: principles and language practices. New York: Pearson Education, Inc.

Cole, F. (2015). Effective strategies for improving writing skills of elementary English language learners. Chicago: ERIC.

Feltsen, P. (2009). Language acquisition and the errors we make. (Thesis). Sundsvall: Mid Sweden University.

Graham, S., \& Hebert, M. (2016). Writing to read: a meta-analysis of the impact ofwriting and writing instruction on reading. Harvard Educational Review, 81(4):710-744. doi:

10.17763/haer.81.4.t2k0m13756113566

Klimova, B. (2013). Approaches to the teaching of writing skills. Procedia Social and Behavioral Sciences 112, 147-151. doi:10.1016/j.sbspro.2014.01.1149 
Laguador, J. M. (2014). Cooperative learning approach in an outcomes-based environment. International Journal of Social Sciences, Arts and Humanities, 2 (2), 2311-3782.

Quarstein, V. A., \& Peterson, P. A. (2001). Assessment of cooperative learning: A goal criterion approach. Innovative Higher Education, 26(1), 59-77.

Slavin, R. E., Hurley, E. A., \& Chamberlain, A. (2003). Cooperative learning and achievement: Theory and research. Handbook of psychology, 177198.

Saad, M. R., \& Sardareh, S. (2013). Defining assessment for learning: a proposed definition from a sociocultural perspective. Life Science Journal 10(2), 2493-2497.

Zechia, D., Balagiu, A., \& Patesan, M. (2016). The benefits of cooperative learning. International conference knowledge-based organization, 22 (2), 478483. 